\title{
Assessing species resistance and productivity of the genus Paeonia L. under adaptation to continental climate conditions
}

\author{
Olga Komina* \\ Central Siberian Botanical Garden of the Siberian Branch of the Russian Academy of Sciences, \\ Novosibirsk, Russia
}

\begin{abstract}
The paper presents results of multiyear work to create and study the collection of Paeonia L. species in the Central Siberian Botanical Garden of the Siberian Branch of the Russian Academy of Sciences (CSBG SB RAS) (Novosibirsk), which numbers 13 species of 4 botanical sections nowadays. All herbaceous species of the genus Paeonia, both geophytes and hemicryptophytes, have been safely wintered during 12 years without additional shelter. The study shows assessment results of prospects of the genus Paeonia species representatives. It gives recommendations on landscape design for Paeonia species selection.
\end{abstract}

\section{Introduction}

The genus Paeonia L. is considered a leading floral culture, it is an inalienable favorite in spring garden [1]. Above 1,000 varieties are grown in Russia today, but recently, due to the changing trends in landscape design, wild Paeonia representatives have become very popular.

The selection criteria of introduction deserving plants are always associated with the evidence of possibilities to grow and breed under new growing conditions, which in turn, is determined by the introducent ability to adapt to other climatic conditions, and resist various pathogens. When working with ornamental plants, the selection criteria is not only an original color, exquisite shape and large dimensions of flowers and inflorescences, but economically valuable qualities, such as the rate of growth, flowering abundance and duration, decorative habitus.

The study objective is to assess the adaptive potential of the genus Paeonia L. species under continental climate conditions of West Siberian forest-steppe.

\section{Material and methods}

Observations and experiments have been carried out since 2007 based on the collection of the Paeonia generic complex of CSBG SB RAS, the collection of living plants in open and covered ground (No USU 440534). The research is gone on the project "Identifying the

\footnotetext{
* Corresponding author: kuznetsova_olga8@mail.ru
} 
ways of plant adaptation to contrasting habitat conditions at population and organism levels" AAAA-A17-117012610053-9 (State Registration No).

All plants have been gathered in natural habitats. The assessment of prospects to introduce peony species of native and non-regional flora has been done in accordance with R.A. Karpisonova's methodology [2].

\section{Results}

At present gathered and studied Paeonia collection of CSBG SB RAS has 13 species from 4 botanical sections, as well as 56 varieties of 5 garden groups (species $P$. biebersteiniana Rupr., $P$. mollis Anderson. are at the primary introduction stage).

While introducing economically valuable plants under continental climate conditions of West Siberian forest-steppe, the main selection criterion is winter resistance, which refers to introducent ability to withstand complex environmental factor impacts in pre-winter, winter and early spring periods.

The genus Paeonia most herbaceous representatives are geophytes, their buds of renewal are at $5 \mathrm{~cm}$ depth of soil surface, that creates favorable conditions for wintering. Some species are hemicryptophytes, e.g. P. obovata Maxim. growing at the Far East under monsoon climate conditions.

During 12 years of studying all herbaceous species of the genus Paeonia safely wintered without additional shelter. The main problems have appeared under attempts to introduce dendriform species of Paeonia ( $P$. suffruticosa Andr.), which need to save an aboveground shoot system during wintering season for adequate flowering the next year.

To select the Paeonia species material for introducing in CSBG SB RAS, the laboratory is guided by the following principles in forming collections of ornamental plants of natural flora [3]: making collections of ornamental plants of the natural flora in frames of generic complexes or their fragments, it is necessary to represent various pheno-rhythm types, life forms and ecological groups. The studied species grew under conditions of temperate continental climate in steppe and mountainous regions, as well as in the temperate monsoon climate (a forest belt). As our introductory experiments show, two pheno-rhythm types were distinguished in our objects during adaptation to the seasonal specifics of natural habitats humidification conditions: spring-summer green and spring-summer-autumn green. However, P. tenuifolia L. vegetated as a hemiephemeroid under moisture deficit in late autumn and early summer some years.

Criteria for selecting Paeonia breeds for the regular style of decoration used in greening the modern urban environment differ greatly of the landscape style requirements [4], which becomes more popular among landscape designers. Related to this we have described biological features of Paeonia species, which create both an early summer aspect of flowering, and the decorative foliaceous effect. After a long winter season, the human visual perception in an urbanized environment is searching for early spring flowers and growing shoots. Representatives of the genus Paeonia belong to the number of not only early growing ornamental perennials. Most Paeonia species, in contrast to breeds, unfurl leaves of original shape and color almost a few days after regrowth.

The final introduction success is evaluated by a set of signs, the most important of which are: completeness of passing a big (ontogenetic) and little life cycle by plants, inherent habitus preservation. When evaluating the Paeonia species of local and non-local flora, each feature was assessed on a three-point scale. As Table 1 shows, complete generative development (which determines seed reproduction) was absent in such species as P. mlokosewitschii Lomak, P. wittmanniana Hartwiss ex Lindl., P. lutea Delavay ex Franch (refers to tree-like plants). In different years these species either did not bloom, or bloomed without forming full seeds. Seed production with a low number of seeds was not 
observed annually in such species as $P$. tenuifolia, $P$. obovata, $P$. oreogeton S. Moore. But $P$. lactiflora Pall., $P$. anomala L., and P. hybrida Pall. had abundant and annual seed production.

Table 1. Assessment of species resistance and productivity of the genus Paeonia of local and nonregional flora by R.A. Karpisonova's methodology

\begin{tabular}{|c|c|c|c|}
\hline $\begin{array}{l}\text { I.Generative } \\
\text { development } \\
\text { determining } \\
\text { seed } \\
\text { reproduction: }\end{array}$ & $\begin{array}{l}1 \text { - seed production is absent (plants } \\
\text { do not bloom; bloom, but seeds do } \\
\text { not form; the seeds do not ripen) } \\
\text { - P. mlokosewitschii } \\
\text { - P. wittmanniana } \\
\text { - P. lutea (refers to dendritic) }\end{array}$ & $\begin{array}{l}2 \text { - seed production } \\
\text { is not annual, few } \\
\text { seeds } \\
\text { - P. tenuifolia } \\
\text { - P. obovata } \\
\text { - P. oreogeton }\end{array}$ & $\begin{array}{l}3-\text { abundant } \\
\text { and annual } \\
\text { seed } \\
\text { production } \\
\text { - P. lactiflora } \\
\text { - P. anomala } \\
\text { - P. hybrida } \\
\end{array}$ \\
\hline $\begin{array}{l}\text { II.Vegetative } \\
\text { reproduction: }\end{array}$ & $\begin{array}{l}1-\text { is absent (plant paresis is not } \\
\text { observed) } \\
\text { - P. lactiflora } \quad-\text { P. mlokosewitschii } \\
\text { - P. oreogeton }- \text { P. wittmanniana } \\
\text { - P. obovata } \quad-\text { P. anomala } \\
\text { - P. hybrida } \quad-\text { P.tenuifolia } \\
\text { - P. lutea }\end{array}$ & - & 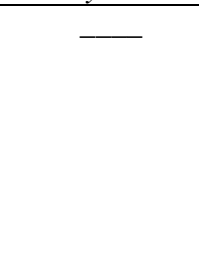 \\
\hline $\begin{array}{l}\text { III. Preserving } \\
\text { habitus and } \\
\text { life-forms in } \\
\text { culture: }\end{array}$ & $\begin{array}{l}1-\text { plants are low, do not reach their } \\
\text { size in nature } \\
-P \text {. lutea }\end{array}$ & $\begin{array}{l}2 \text { - retain natural } \\
\text { sizes } \\
-P . \text { tenuifolia } \\
-P . \text { obovata } \\
-P . \text { oreogeton } \\
-P . \text { wittmanniana } \\
-P . \text { mlokosewitschii }\end{array}$ & $\begin{array}{l}\text { 3- exceed } \\
- \text { P. lactiflora } \\
-P . \text { anomala } \\
-P . \text { hybrida }\end{array}$ \\
\hline $\begin{array}{l}\text { IV.Plants } \\
\text { survival of in } \\
\text { unfavorable } \\
\text { seasons } \\
\text { (determined } \\
\text { by } \\
\text { recalculation): }\end{array}$ & $\begin{array}{l}1 \text { - considerable annual dying off } \\
\text { shoots and specimens }\end{array}$ & $\begin{array}{l}2 \text { - shoots and } \\
\text { specimens die only } \\
\text { in especially severe } \\
\text { winter } \\
-P . \text { mlokosewitschii } \\
\text { - P. wittmanniana } \\
\text { - P. lutea }\end{array}$ & $\begin{array}{l}\text { 3- plants do } \\
\text { not drop off } \\
-P . \text { lactiflora } \\
\text { - P. tenuifolia } \\
\text { - P. anomala } \\
\text { - P. hybrida } \\
\text { - P. oreogeton } \\
\text { - P. obovata } \\
\end{array}$ \\
\hline
\end{tabular}

Natural vegetative reproduction (plant paresis) was not observed in $P$. lactiflora, $P$. mlokosewitschii, P. oreogeton, $P$. wittmanniana, $P$. obovata, $P$. anomala, $P$. hybrida, $P$. tenuifolia, $P$. lutea. To accelerate Paeonia species reproduction aimed their conservation ex situ, we made artificial vegetative propagation by a bush dividing.

When evaluating the habitus and life form preservation in culture, P. lutea got 1 point, as it did not develop a heavy system of aboveground skeletal axes, and did not reach sizes inherited in nature.

P. tenuifolia, P. obovata, P. wittmanniana, P. mlokosewitschii retained their natural sizes (2 points). Only $P$. lactiflora and $P$. anomala exceeded their inherent natural size (maximum score of 3 points), which might be due to similarity of natural habitat conditions against and competition lack in a cenosis, as well as a high level of agricultural technology in cultivation.

Practically, all studied species were character a high survival rate of plants in unfavorable seasons. None of 9 species was marked by annual specimen dying off. Individual shoots dying off was observed in $P$. mlokosewitschii, $P$. wittmanniana, and $P$. lutea only in extremely harsh winters with a sharp long temperature decrease in November and insufficient snow cover; they received 2 points according to this sign. P. lactiflora, $P$. 
tenuifolia, $P$. anomala, $P$. oreogeton, $P$. obovata obtained the maximum score (3 points), as they did not show dropping off shoots or specimens.

Cluster analysis showed that the studied species-introducents of the genus Paeonia should be shared three groups according to the degree of their outlooks for West Siberian forest-steppe.

The first group includes 3 species $P$. lactiflora, $P$. anomala, P. hybrida - received the greatest assessment of prospects according to R.A. Karpisonova's scale (10 points). All of them are marked as species growing under the natural conditions in Siberia [5]. This is a local species of $P$. anomala, as well as $P$. hybrida growing close to Novosibirsk Region (Altai Republic, Altai Territory), and P. lactiflora, a species introduced from Primorye with a wide range (East Siberia-Far East).

The second group consists of two Primorye species, P. oreogeton, P. obovata growing in nature at the Far East, and P. tenuifolia from the Stavropol Region, these 3 species are confined to a fairly wide range of habitats, which indicate their broad ecological plasticity (8 points each).

The third group includes two Caucasian species, $P$. wittmanniana and $P$. mlokosewitschii, which natural habitat conditions differ greatly from the climatic conditions of West Siberian forest steppe ( $P$. mlokosewitschii is endemic of Central and Eastern Caucasus) (6 points each). $P$. lutea enter this same group as well; it received the smallest score (5 points) on stability and productivity in our region, that is not surprising for a species related to tree-like plants, which do not retain their biomorphs inherited in nature under severe climatic conditions of West Siberian forest-steppe.

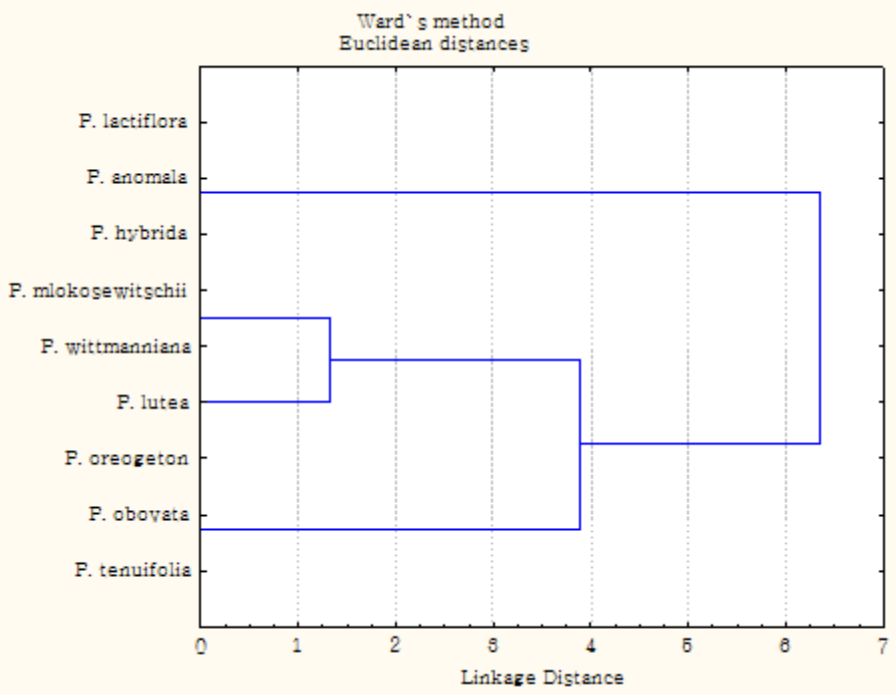

Fig. 1. Cluster analysis on resistance and productivity parameters of the genus Paeonia species of local and non-regional flora.

\section{Discussion}

The comparative assessment of prospects revealed that a local species $P$. anomala, as well as the tested non-regional species $(P$. lactiflora, $P$. mlokosewitschii, $P$. oreogeton, $P$. wittmanniana, $P$. obovata, $P$. hybrida, $P$. tenuifolia, $P$. lutea) showed themselves highly plastic adapted to climatic conditions, which can successfully grow in West Siberian foreststeppe. P. oreogeton, P. mlokosewitschii and P. wittmanniana need preliminary choice of 
optimal microecological conditions, after which they bloom successfully and bear seed regularly.

P. tenuifolia, which does not form self-sowing (by the way, it is not a positive sign for flower gardens), does not concede to species forming high, albeit longer, flowering effect.

In analyzing the genus Paeonia species stability and productivity compared with similar studies by other researchers, it was concluded that $P$. anomala is the most deserving plant for both Bashkir Pre-Ural forest-steppe [6, 7], and Belarus' [8], in Kemerovo Region it is even recommended for plantation cultivation [9].

To study plant biodiversity conservation ex situ, the methodology by R. A. Karpisonova [1] is the most informative to assess the adaptive features of perennial grass polycarpic species. Evaluating the prospects of Paeonia species as ornamental plants it is necessary to pay attention to such decorative elements as leaf and fruit shape, their color in addition to the flowering effect.

\section{Conclusion}

Thus, while determining resistance and productivity, P. lactiflora, P. anomala, P. hybrida have got the highest scores (10 points); they exceed the inherited bush size and maintain abundant and annual seeding.

$P$. tenuifolia, P. obovata, $P$. oreogeton (8 points) are considered promising as well, because they retain the bush natural size and form seeds being introduced into more severe climatic conditions.

Such Paeonia species as $P$. lactiflora, $P$. anomala, $P$. hybrida (10 points), $P$. tenuifolia, $P$. oreogeton, $P$. obovata (8 points) occur highly winter-resistant; $P$. mlokosewitschii, $P$. wittmanniana (6 points), and $P$. lutea (5 points) are rather winter-resistant (particular units drop off). Cluster analysis has confirmed the obtained experimental data.

None of 9 species does reveal specimen dying off. In general, the Paeonia species should be regarded sufficiently winter-resistant objects, which give a high decorative effect not only in the flowering period, but as well due to a heavy compact bush habitus and beautiful foliage. However, their decorative effect can reduce by diseases and pests under local conditions.

For Paeonia species identified as promising it is useful to recommend the most effective combinations with other less common ornamental plants. For instance, mixborder bright fragments will be small groups formed by P. tenuifolia, Trollius asiaticus L., T. europaeus L.; P. obovata, Primula juliae Kusn., Primula pallasii Lehm.; P. lactiflora, and $T$. ledebourii Reichb.

This assortment of peony species may be successful in applying to create wildlife fragments in the urbanized urban environment, which are popular landscape design direction nowadays.

\section{References}

1. R. Kamenetsky, J. Dole, Floriculture Ornament. Biotechnol. 1, 6 (2012)

2. R.A. Karpisonova, Herbaceous plants deciduous forests of the USSR: ecologic-floristic and introduction characteristics (Nauka, Moscow, 1985) in Russ.

3. T.I. Fomina Biological characteristics of ornamental plants of natural flora in West Siberia (Geo, Novosibirsk, 2012) in Russ.

4. N. Müller, H. Sukopp, Landscape Ecol. Eng. 12, 1 (2016) 
5. N.V. Friesen, Paeonia L. - Peony, Flora Sibiriae. (6, Nauka, Novosibirsk, 1993) in Russ.

6. A.A. Reut, Bull. OGU. 12 (2017) in Russ.

7. A.A. Reut, L.N. Mironova, Ital. Sci. Rev. 7, 16 (2014)

8. V.V. Gayshun, Proc. Natl Acad. Sci. Belarus. 4 (2015) in Russ.

9. Y. V. Zagurskaya, I. N. Yegorova, Bull. ASAU. 12, (2015) in Russ. 